\title{
Forest Vegetation Cover in Binh Chau - Phuoc Buu Nature Reserve in Southern Vietnam
}

\author{
Viet Hung Dang ${ }^{1}{ }^{2 *}$, Alexander Potokin', Thi Lan Anh Dang2, Thi Ha Nguyen², \\ and Van Son $\mathrm{Le}^{3}$ \\ ${ }^{1}$ Saint-Petersburg State Forest Technical University, Instytutskiy 5U, 194021, St. Petersburg, Russia \\ ${ }^{2}$ Vietnam National University of Forestry - Dong Nai Campus, Vietnam, Dong Nai Province, Trang \\ Bom District, Trang Bom town, Tran Phu st., 54 \\ ${ }^{3}$ Binh Chau - Phuoc Buu Nature Reserve, Ba Ria - Vung Tau Province, Xuyen Moc District, Vietnam
}

\begin{abstract}
Binh Chau - Phuoc Buu Nature Reserve is located in the tropical rainforest zone of southeast Vietnam. The obtained results from the study undertaken on the composition of plant species and forest vegetation in Binh Chau - Phuoc Buu Nature Reserve indicated a record of 743 species, 423 genera and 122 families that belongs to the three divisions of vascular plants. These includes: Polypodiophyta, Pinophyta and Magnoliophyta. Useful plants of 743 taxonomy species listed consists of 328 species of medicinal plants, 205 species of timber plants, 168 species of edible plants, 159 species of ornamental plants, 56 species of industrial plants, 10 species of fiber plants and 29 species of unknown use plants, respectively. During the duration of investigation, Nervilia aragoana Gaudich. was newly recorded in the forest vegetation of Binh Chau Phuoc Buu Reserve. A variety of forest vegetations in the area under study is described. In this study, two major vegetation types of forest were identified in Binh Chau - Phuoc Buu Reserve.
\end{abstract}

\section{Introduction}

In accordance with Decision №194/CT of 08/09/1986, Binh Chau - Phuoc Buu Nature Reserve (hereafter BC-PB Reserve) was recognized as a specially protected natural area of Vietnam by the Prime Minister of the Republic of Vietnam [6]. The object of study is located in the province of Ba Ria - Vung Tau, with an area of 11293 ha, between $10^{\circ} 27^{\prime} 57^{\prime \prime}$ - 10 $0^{0} 37^{\prime} 46^{\prime \prime}$ north latitude and $107^{0} 24^{\prime} 31^{\prime \prime}-107^{0} 36^{\prime} 07^{\prime \prime}$ east longitude (fig. 1).

BC-PB Reserve is the only remaining natural of deciduous dipterocarp forest, located on the coast of SouthernVietnam. Rare, valuable and endemic species of flora and fauna, listed in the Red Book of Vietnam and the International Union for Conservation of Nature (IUCN), live in BC-PB Reserve. However, in recent years, the structure of forest vegetation cover in BC-PB Reserve has changed. This led to a change in the habitat of plants and animals, the number of individuals decreased, and many rare and endangered species were threatened. Therefore, the issue of forest conservation in BC-PB Reserve plays an important role.

\footnotetext{
* Corresponding author: viethung@vnuf2.edu.vn
} 


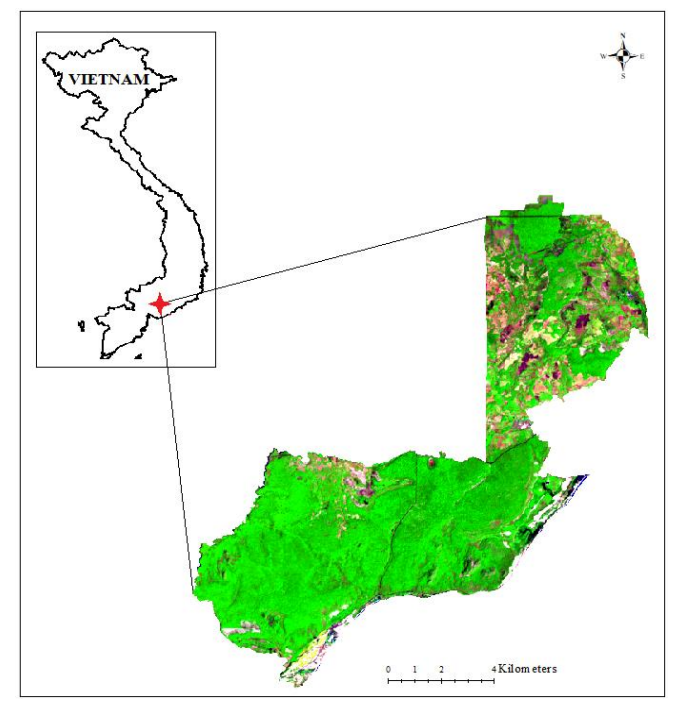

Fig. 1. Binh Chau - Phuoc Buu Nature Reserve location in Southern Vietnam

\section{Materials and Methods}

\subsection{Materials}

The objects for research were forest ecosystems on the territory of BC-PB Reserve. Ecological and geographical analysis of the species composition of forests in the reserve indicates certain links between regions and environmental conditions reveals their environmental specificity.

\subsection{Methods}

Geobotanical and floristic study was carried out on the 35 plots $(20 \times 20 \mathrm{M})$ [4], [9] (Figure 1). We established 16 transects, which covered the whole surface area of BC-PB Reserve. The total length of these transects combined is about $20 \mathrm{~km}$. In each transect we marked all species and collected specimens of plants which could not be identified in the field. We also collected many plants outside the plots and traverses, to make sure that our inventory was as representative of the entire area with species of the local flora [1].

Voucher species were sent to the Herbarium of the Vietnam National University of Forestry - Dong Nai campus and other specialists for identification. Plant species were identifed with reference to An Illustrated of Flora of Vietnam [5].

The vegetation types of BC-PB Reserve were classified according to Thai Van Trung [8]. Additionally, the human disturbance levels of the vegetation were determined by noting the number of tree stumps and number of foot paths in the plots [3].

From 2019-2020, the research team conducted many surveys in Binh Chau, Bung Rieng, Bong Trang and Phuoc Thuan villages in BC-PB Reserve. Field research was conducted to gain intensive understanding of people through discussions and interactions. Primary data was gathered initially through household interviews based on questionnaires, Rapid Rural Appraisal (RRA), and the "walk in the woods" method [2]. 


\section{Results and discussion}

\subsection{Vegetation types in BC-PB Reserve}

The vegetation of BC-PB Reserve is dominantly lowland forest type with the highest peak level of about $160 \mathrm{~m}$ [8]. Among the natural vegetations of BC-PB Reserve there is a major dichotomy between the evergreen forests on lowland types and other types of formations. The composition of the vegetation in BC-PB Reserve is identified by 2 major types: tropical evergreen broad-leaved semi-deciduous and plantation forest.

Tropical evergreen broad-leaved semi-deciduous forest (fig. 2). This forest type covers about 8883 ha (84,3\%). Dominant families are Dipterocarpaceae, Lythraceae, Sapindaceae, Myrtaceae, Sterculiaceae, Anacardiaceae, etc... The forest structure is simple with three layers: The canopy layer is composed mainly of Parinari annamensis, Irvingia malayana, Dipterocarpus condorensis, Lagerstroemia calyculata, Sindora siamensis, Hopea odorata, Anisoptera costata, Shorea roxburghii, Melanorrhoea usitata, Melanorrhoea laccifera, Fagraea fragrans, Vitex ajugaeflora, Markhamia stipulata, Litsea pierrei, Terminalia triptera, Xylopia vielana, Diospyros maritima, Diospyros variegata, Syzygium chanlos, Syzygium cinereum, Syzygium tinctorium, Syzygium zeylanicum, Cratoxylon cochinchinensis, Cratoxylon formosum, etc... The shrub layer is composed of many species, with as dominant ones Ixora delpyana, Psychotria adenophylla, Randia dasycarpa, Hyptis rhomboidea, Scoparia dulcis, Clerodendrum tonkinensis, Dracaena angustifolia, etc... The herb layer is composed mainly of species are Homalomena pierreana, Peliosanthes teta, Typhonium trilobatum, Asparagus cochinchinensis, Flagellaria indica, Chrysopogon aciculatus, Dactyloctenium aegyptiacum, Panicum repens, Vetiveria zizanoides, Globba pendula, Kaempferia galanga, Kaempferia champasakensis and some other species.

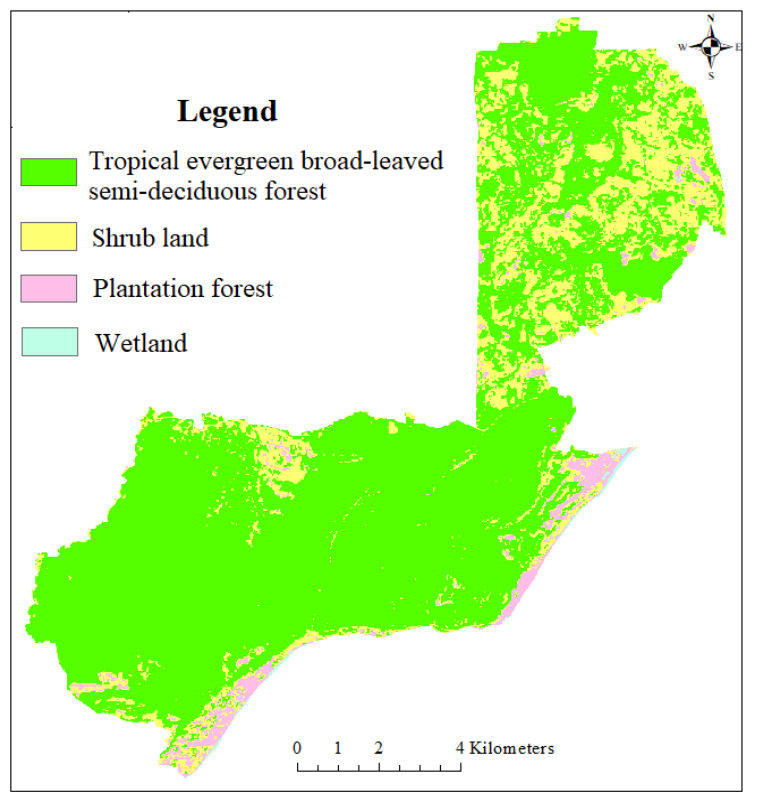

Fig. 2. Forest vegetation types of Binh Chau - Phuoc Buu Reserve.

Plantation forest. This forest type covers about 1165 ha. The following species, such as: Acacia auriculiformis, Afzelia xylocarpa, Dipterocarpus condorensis, Shorea roxburghii, 
Anisoptera costata, Pterocarpus macrocarpus, etc... are planted in plantation forest of BCPB Reserve. The structure of this forest type is simple; it includes the tree layer and a ground layer with mainly weedy species belonging to families Poaceae, Rubiaceae, Euphorbiaceae, Asteraceae.

\subsection{Floristic diversity in BC-PB Reserve}

During our investigations, 743 vascular plant species belong to 423 genera and 122 families were identified in BC-PB Reserve can be seen in Table 1. At the period time, two species of plants were newly recorded in literature devoted to the flora of Vietnam, named Stereospermum binhchauensis V.S. Dang [7] and Kaempferia champasakensis Pichean. \& Koonterm [10]. The present study recorded one new species in BC-PB Reserve, named Nervilia aragoana Gaudich. in Orchidaceae.

Table 1. Summary on the floristics of BC-PB Reserve.

\begin{tabular}{|l|l|c|c|c|}
\hline № & \multicolumn{1}{|c|}{ Taxa } & Family & Genus & Species \\
\hline 1. & Polypodiophya & 7 & 11 & 15 \\
2. & Pinophya & 2 & 2 & 3 \\
3. & Magnoliophya & 113 & 410 & 725 \\
\hline \multicolumn{2}{|c|}{ Total } & 122 & 423 & 743 \\
\hline
\end{tabular}

Among the investigated 743 species, 6 endemic species in Vietnam were also included. Many plant species are endemic to Vietnam (the species were first records in Vietnam and scientific names take the places of Vietnam) and endemic plants of local (the first records of species in BC-PB Reserve) such as Stereospermum binhchauensis (Table 2).

Table 2. List of endemic plants in BC-PB Reserve.

\begin{tabular}{|llll|}
\hline No. & Family name & Scientific name & Vietnamese name \\
\hline 1. & Arecaceae & Calamus dongnaiensis Pierre ex Conrad & Mây Đồng Nai \\
2, & Bignoniaceae & Stereospermum binhchauensis V.S. Dang & Quao Bình Châu \\
3. & Dipterocarpaceae & $\begin{array}{l}\text { Dipterocarpus condorensis Pierre } \\
\text { Gigantochloa dinhensis (A. Camus) T.Q. }\end{array}$ & Dầ Côn Sơn \\
4. & Poacea & Nguyen & Le núi Dinh \\
& & & Aesandra dongnaiensis Pierre \\
5. & Sapotaceae & & Xantolis dongnaiensis (Pierre \\
& & & ex Dubard) \\
6. & Sapotaceae & Aubrév. \\
\hline
\end{tabular}

In BC-PB Reserve, useful plants of 743 species listed consists of 328 species $(35.4 \%)$ of medicinal plants (Me), 205 species $(21.5 \%)$ of timber plants (Ti), 168 species $(17.6 \%)$ of edible plants (Ed), 159 species $(16.6 \%)$ of ornamental plants (Or), 56 species $(5.9 \%)$ of industrial plants (In), 10 species (1.0\%) of fiber (Fi) and 29 species (3.0\%) of unknown use plants (Un), respectively in Table 3.

Table 3. Usefulness of plant resources in BC-PB Reserve.

\begin{tabular}{|llllllll|}
\hline Uses & $\mathrm{Me}$ & $\mathrm{Ti}$ & $\mathrm{Ed}$ & $\mathrm{Or}$ & $\mathrm{In}$ & $\mathrm{Fi}$ & Un \\
\hline Species & 35.4 & 205 & 168 & 159 & 56 & 10 & 29 \\
$\%$ & 35.4 & 21.5 & 17.6 & 16.6 & 5.9 & 1.0 & 3.0 \\
\hline
\end{tabular}

The plant resources of BC-PB Reserve are valuable not only because of the great diversity, but also have great environmental importance. As part of the flora of BC-PB Reserve, 25 species of 743 plant species were listed in the Red book of Viet Nam (2007) 
[11]. In the red book of IUCN (2020) [12], 7 species were classified as endangered species (EN), 6 species were classified as vulnerable species (VU) and 5 species were classified as least concern (Table 4).

Table 4. List of endangered and rare plants in BC-PB Reserve.

\begin{tabular}{|c|c|c|c|}
\hline No. & Scientific name & VRDB (2007) & IUCN (2020) \\
\hline 1. & Aeginetia indica $\mathrm{L}$. & VU & \\
\hline 2. & Afzelia xylocarpa (Kurz) Craib & $\mathrm{EN}$ & EN \\
\hline 3. & Alstonia scholaris (L.) R. Br. & & $\mathrm{LC}$ \\
\hline 4. & Anisoptera costata Korth. & EN & EN \\
\hline 5. & Biancaea sappan (L.) Tod. & & $\mathrm{LC}$ \\
\hline 6. & Cycas lindstromii S. L. Yang, K. D. Hill \& N. T. Hiep & & EN \\
\hline 7. & Cycas pectinata Griff. & VU & VU \\
\hline 8. & Dalbergia oliveri Gamble ex Prain & EN & EN \\
\hline 9. & Dipterocarpus costatus C.F.Gaertn. & & VU \\
\hline 10. & Dipterocarpus dyeri Pierre & VU & EN \\
\hline 11. & Drynaria bonii Christ. & VU & \\
\hline 12. & Dysoxylum loureirii Pierre. & VU & \\
\hline 13. & Euonymus cochinchinensis Pierre & & $\mathrm{LC}$ \\
\hline 14. & Homalomena pierreana Engler. & VU & \\
\hline 15. & Hopea ferrea Lanessan & EN & EN \\
\hline 16. & Hopea odorata Roxb. & & VU \\
\hline 17. & Markhamia stipulata (Wall.) Seem & & $\mathrm{LC}$ \\
\hline 18. & Peliosanthes teta André. subsp. Teta & VU & \\
\hline 19. & Psydrax dicoccos Gaertn. & VU & VU \\
\hline 20. & Pterocarpus macrocarpus Kurz & EN & EN \\
\hline 21. & Sindora siamensis Teijsm. ex Miq. & EN & $\mathrm{LC}$ \\
\hline 22. & Stemona pierrei Gagnep. & VU & \\
\hline 23. & Tacca integrifolia Ker.-Gawl. & VU & \\
\hline 24. & Vitex ajugaeflora Dop & & VU \\
\hline 25. & Xylopia pierrei Hance & VU & VU \\
\hline
\end{tabular}

Note: VRDB - Vietnam Red Data Book (2007); IUCN - Global conservation status (2020); EN Endangered; VU - Vulnerable; LC - Least Concern

\section{Conclusions}

BC-PB Reserve is characterized by two major vegetation types of forest: tropical evergreen broad-leaved semi-deciduous and plantation forest.

The diversity of plant species in BC-PB Reserve was studied to provide baseline information for conservation and sustainable management processes that will prolong the the life of the reserve. A total of 743 species of vascular plants are recorded in BC-PB Reserve belonging to 432 genera and 122 families. From the indicated species Nervilia aragoana is new record species for the flora in BC-PB Reserve.

The useful plant resources were divided into seven groups as follows: medicinal plants with 328 species, timber plants with 205 species, edible plants with 168 species, ornamental plants with 159 species, industrial plants with 56 species, fiber plants with 10 species and unknown use plants with 29 species.

Besides this survey, the forest areas were explored, concentrating on the useful plants and it was recorded that BC-PB Reserve has 6 endemic species, 25 species subject to global-level and national-level conservation.

The authors are thankful to the Department of Forest Plant, Vietnam National University of Forestry - Dong Nai Campus and Department of Botany and Dendrology, St. Petersburg State Forest 
Technical University (Russia), for granting permission to carry out study. We are thankful to Ass. Prof. PhD Potokin Alexander F., Dr. Dang Viet Cuong for specimen identification. We also thank Prof. Doctor Neshatayev Vasily Yu. for comments on an early draft of the article.

\section{References}

1. V.H. Dang, A.F. Potokin, Diversity of plant species composition and forest vegetation cover of Dong Nai Culture and Nature Reseve, Vietnam, Earth and Environmental Science, 316, 1-9 (2019) doi:10.1088/1755-1315/316/1/012009

2. T.S. Dinh, K. Hyakumura, K. Ogata, Livelihoods and Local Ecological Knowledge in Cat Tien Biosphere Reserve, Vietnam: Opportunities and Challenges for Biodiversity Conservation // The Biosphere, Natarajan Ishwaran, IntechOpen, (2012) https://www.intechopen.com/books/the-biosphere/livelihoods-and-local-ecologicalknowledge-in-cat-tien-biosphere-reserve-vietnam-opportunities-and-c

3. V.S. Hoang, P. Baas, P.J. Keßler, Economic Botany, 62574 - 593 (2008)

4. T.T. Nguyen, P.J. Baker, Plant Ecology \& Diversity, 9, 5-6 (2016) doi:10.1080/17550874.2016.1210261 pp 589-601

5. H.H. Pham, Cây Cỏ Việtnam [In Vietnamese - An Illustrated Flora of Vietnam], 1-3, 202-208, 295-296 (1999)

6. Report on Assessment of the Special-use Forest System and its Management in Ba RiaVung Tau Province Hanoi (2002)

7. D.V. Son, Acta Phytotaxonomica et Geobotanica, 66 (2), 91-94 (2015)

8. V.T. Thai, Những hệ sinh thái rừng nhiệt đới Việt Nam [In Vietnamese - The forest ecosystems in tropical Vietnam] (NXB Khoa học và Kỹ Thuật, Hồ Chí Minh, 1999)

9. H.T. Thanh Do, J.C. Grant, B.N. Trinh, H.C. Zimmer, J.D. Nichols, Journal of AsiaPacific Biodiversity, (2017) doi: 10.1016/j.japb.2017.08.008

10. T.K.V. Tran, P.N. Nguyen, V.S. Le, V. Hoang, A new record species for Vietnam, 2(1), 13 - 18 (2018) (in Vietnamese)

11. Ministry of science and technology of Vietnam. Red book. Part 2: plants. (Science and technology publishing House, Hanoi, 2007)

12. https://www.iucnredlist.org/ (accessed April 10, 2020). 